This is the post-print version of the final paper published in World Development, 38(3), 260-269, 2010. The published article is available at http://www.sciencedirect.com/science/article/pii/S0305750X09001740.

Changes resulting from the publishing process, such as peer review, editing, corrections, structural formatting, and other quality control mechanisms may not be reflected in this document. Changes may have been made to this work since it was submitted for publication. Copyright @ 2009 Elsevier B.V.

\title{
A critical appraisal of McKinnon's complementarity hypothesis: Does the real rate of return on money matter for investment in developing countries?
}

\author{
Tomoe Moore \\ Department of Economics and Finance, Brunel University \\ Uxbridge, Middlesex, UB8 3PH, United Kingdom \\ Tel: +441895267531 \\ Fax: +441895269770 \\ tomoe.moore@brunel.ac.uk
}




\title{
A critical appraisal of McKinnon's complementarity hypothesis: Does the real rate of return on money matter for investment in developing countries?
}

\begin{abstract}
SUMMARY
McKinnon's (1973) complementarity hypothesis predicts that money and investment are complementary due to self-financed investment, so that a real deposit rate is the key determinant of capital formation for developing economies. This paper critically appraises this contention by conducting a vigorous empirical approach using panel data for 107 developing countries. The long-run and dynamic estimation results based on McKinnon's theoretical model are supportive of the hypothesis. However, when the investment model is conditioned by such factors as financial development, different income levels across developing countries, external inflows, public finance and trade constraints, the credibility of the hypothesis is undermined.
\end{abstract}

KEYWORDS: McKinnon's complementarity hypotheses, Capital formation, Developing countries, Real deposit rates, Money, Credit

JEL CLASSIFICATION: E4, O1

\section{ACKNOWLEDGEMENT}

The author is grateful to the editor and three anonymous referees of this journal for their valuable comments and suggestions. Usual disclaimers apply. 


\section{INTROCUTION}

The argument for self-financed capital formation within financially constrained developing economies led McKinnon (1973) to develop a complementarity hypothesis, whereby high real rates of return on money bring about the accumulation of real money balances, and these, in turn, finance the costly, indivisible fixed physical capital. The hypothesis formulates a dual process, in which the demand for real money balances depends directly, inter alia, on the average real return on capital, and the investment ratio to GDP rises with the real interest rate on deposits. This process provided a plausible empirical framework for researchers to analyse investment decisions and the demand for money function for developing countries. Most of the literature engages in a single equation framework, either in a money or in an investment equation. For example, DeMelo and Tybout (1986), Edwards (1988) and Morriset (1993) focused on the investment equation, whereas Harris (1979) and Thornton and Poudyal (1990) modelled the demand for money function. The study of Fry (1978), Laumas (1990), Thornton (1990) and Khan and Hasan (1998) tested the complementarity hypothesis by estimating both investment (or savings) and the demand for money functions. Pentecost and Moore (2006) investigated the interdependence between the investment and money legs of the joint hypothesis in a simultaneous system of equations for India. Overall, whether the coverage of a sample country is either a single country or a group of several countries, the empirical literature tends to support the complementarity hypothesis.

This paper critically appraises McKinnon's complementarity hypothesis by conducting a vigorous empirical approach using panel data for 107 developing countries with the sample period of 1970 to 2006 . First, we test a panel cointegration for the key variables of money, investment, real return on money, aggregate income and credit. The presence of cointegration is a pre-requisite for the acceptance of the hypothesis. Secondly, the long run relationship is modelled in a panel system of equations, followed by an error correction 
dynamic model. We then extend the theoretical model by conditioning the investment behaviour by incorporating the effect of financial development, different income levels across developing countries, external inflows, trade constraints and public finance. These variables are mostly predicted to increase capital formation independently of the hypothesis.

We find a cointegration relationship among the key variables, which provides a necessary condition for the complementarity hypothesis. The long-run and dynamic estimates are supportive, too, since we find a statistically significant effect of return on capital on the demand for money model, and also a significant positive impact of real deposit rates on investment. Evidence also reveals that financial development and the status of having a middle-income level among developing economies are factors, which reduce selffinanced capital formation by mitigating financial constraints. The conditional variables are found to boost the economy by accumulating physical capital independently of the selffinance hypothesis. Although real deposit rates are found to be statistically significant, even after augmenting the investment model with the conditional variables, the size of the coefficients significantly declines, undermining the credibility of self-financed capital formation. The empirical result highlights the key role of financial intermediation through the conduit of credit for increased capital formation.

The structure of the paper is as follows. In Section 2, McKinnon's (1973) complementarity hypothesis is specified. Section 3 describes the data employed for estimation, and Section 4 spells out the panel unit root and cointegration tests. Long-run and dynamic models are estimated in Section 5. In Section 6, the investment long-run model is augmented with conditional variables. Section 7 concludes. 


\section{MCKINNON'S COMPLEMENTARITY HYPOTHESIS}

McKinnon (1973) asserts self-finance and lump-sum expenditure or indivisibilities of investment for financially-constrained developing countries, hence investors are obliged to accumulate money balances prior to their investment project. Meanwhile, in many developing countries, the decades of high budget deficits have resulted in high domestic borrowings by the government, forcing them to lower their borrowing costs. Consequently, government securities at low interest rates became one of the major causes of financial repression, where interest rates were set by administrative decision, and they were likely to be below market-determined levels (Fry 1980). McKinnon emphasises that the removal or relaxation of the administered interest rates would boost capital formation, since high deposit rates attract the accumulation of money, and stimulate investment.

The complementarityy hypothesis is examined using money and investment models. First, the demand for real money balances $(M / P)$ depends positively upon real income, $Y$, the own real rate of interest on bank deposits, $d-\pi^{e}\left(d=\right.$ deposit rates and $\pi^{e}=$ expected rate of inflation), and the real average return on capital, $c$. The positive association between the average real return on physical capital and the demand for money balances represents the complementarity between capital and money as given by (time scripts are omitted for simplicity).

$$
M / P=\Psi\left(Y, c, d-\pi^{e}\right) \quad \Psi_{Y}>0, \Psi_{c}>0, \Psi_{d-\pi^{e}}>0
$$

The equation (1) suggests that the demand for money is given not only by the transactions motive of holding cash, but also by the need to finance real capital formation in countries where institutional credit or alternative finance are constrained. There is also the need to hedge against inflation in such a way as to preserve the real value of money balances. 
The complementarity works in both directions: money supply has a first order impact in determining investment, hence complementarity can be accomplished by specifying an investment function given by:

$$
I / Y=F\left(c, d-\pi^{e}\right) \quad F_{c}>0, F_{d-\pi^{e}}>0
$$

The investment to income ratio, $I / Y$, must be positively related to the real rate of return on money balances. This is because if a rise in the real return on bank deposits, $d-\pi^{e}$, raises the demand for money, and real money balances are complementary to investment, it must also lead to a rise in the investment ratio. The complementarity hypothesis specifically requires that $\Psi_{c}>0$ and $F_{d-\pi^{e}}>0^{1}$.

McKinnon's model is, however, restrictive in that it is assumed that there is no intermediation by financial institutions between saving (money includes current and time savings) and the creation of credit. This is very unlikely, even in under-developed financial markets. Since the indirect effect of real deposit rates on investment is due, not only to selffinance, but also to the credit creation from money, where the real supply of credit increases pari passu money demand (Fry 1980). Moreover, the level of credit may contain two types of information about the process of financial intermediation. First, changes in credit may reflect the ability of financial intermediaries to make loans perhaps due to changes in monetary policy. In this case, firms, which are unable to obtain funds in the capital market, may become creditconstrained, leading to lower levels of investment. Second, changes in credit may reflect shocks to the intermediation system itself. In particular, financial liberalisation, undertaken in many developing countries, initiates various forms of deregulation of financial markets, the creation of financial innovations, or perhaps changes in the solvency of borrowers or lenders; these have implications for economic activity that may be transmitted through changes in the quantity of credit (Mallick and Moore 2008). In this respect, the availability of credit to business will affect the investment ratio independently of the self-finance motive for holding 
money, hence the variable of 'credit' can be specified in the investment equation. By specifying credit along with the real rates of deposit in the investment equation, two channels of funding sources could be identified: one is self-finance portrayed by the effect of real deposit rates, and the other channel is through credit intermediated by financial institutions.

From an empirical perspective, it is impossible to compute a sensible measure of the real return on physical capital across countries. Hence, following Khan and Hasan (1998), Laumas (1998) and Pentecost and Moore (2006), it is proxied by the investment to income ratio, $I / Y$, which is likely to vary directly with the average real return on capital ${ }^{2}$. The models now become:

$$
\begin{aligned}
& m / p=\psi\left(y, i / y, d-\pi^{e}\right) \\
& i / y=f\left(d-\pi^{e}, d c\right)
\end{aligned}
$$

where $m / p=\ln (M / P), i / y=\ln (I / Y)$ and $y=\ln (Y / P) . d c$ is the ratio between domestic credit to private sector and GDP. The models (3) and (4) form a basis for empirical estimation.

\section{DATA}

The data set used to estimate models (3) and (4) is the annual data of 107 developing countries covering the period 1970 to 2006 . The time series per country contain a minimum of 7 years in sequence. See Appendix 1 for country details. Note that the study covers more than $70 \%$ of all developing countries, with a total of 149 countries classified as developing countries based on 2006 GNI per capita.

Broad money $(M)$ includes money and quasi money (demand and time deposits), and the deposit rates $(d)$ are the rates paid by commercial or similar banks for demand, time, or savings deposits. The consumer price index $(p)$ is used as the deflator for nominal GDP $(Y)$ and the broad money stock, and it is also used to compute inflation. Note that some observations of extremely volatile real deposit rates $\left(d-\pi^{e}\right)$ are excluded from the empirical 
analysis $^{3}$. The capital formation for the private sector $(I)$ is derived from the gross fixed capital formation ${ }^{4}$. Expected inflation in $d-\pi^{e}$ is not directly observable. For a volatile rate of inflation in developing economies, where the future prediction of the variable is extremely difficult, an autoregressive type of expectation seems to be reasonable. We take a naïve expectation, i.e. $\pi_{t+1}^{e}=\pi_{t}{ }^{5}$. All these data are taken from World Development Indicators. The descriptive statistics are found in Appendix 2.

\section{PANEL UNIT ROOT AND COINTEGRATION TESTS ${ }^{6}$}

The complementarity hypothesis predicts the linkage between money and investment, and that the dependent and independent variables in equations (3) and (4) are likely to form a stable long-run relationship, hence, we carried out unit root and cointegration tests.

For unit root tests, Fisher's (1932) ADF and PP tests proposed by Maddala and Wu (1999) would fit for unbalanced panel data. Maddala and Wu (1999) assume individual unit root processes, and combine the $p$-values from individual unit root tests. We also conducted two other types of panel unit root tests, developed by Levin et al. (2002) and Im et al. (2003) for the robustness check. Levin et al. (2002) assume that there is a common unit root process so that coefficients on the lagged dependent variables are homogeneous across cross-sections. In contrast, Im et al. (2003) allow for heterogeneity of the coefficients on the lagged dependent variable with the slope coefficients to vary across cross-sections. Based on these tests, we found that the variables of $m / p, d c$ and $y$ were characterised as integrated of order one, I(1), whereas $i / y$ and $d-\pi^{e}$ were stationary, i.e. $\mathrm{I}(0)$.

For a panel cointegration test, Fisher (1932) derives a combined test that uses the results of the individual independent tests, and Maddala and Wu (1999) extend Fisher's test by developing a Johansen panel cointegration test, which combines tests from individual cross-sections for the full panel. If $\omega_{i}$ is the $p$-value from an individual cointegration test for 
cross-section $i$, then under the null hypothesis for the panel, we have $-2 \sum_{i=1}^{N} \log \left(\omega_{i}\right) \rightarrow \chi_{2 N}^{2}$. The trace and maximum eigenvalue tests suggests that there are four cointegrating vectors found at the conventional significance level ${ }^{7}$. Note that the inclusion of $\mathrm{I}(0)$ variables (i.e. $i / y$ and $\left.d-\pi^{e}\right)$ appears to have increased the number of cointegration vectors, since each $\mathrm{I}(0)$ variable is stationary by itself, and it forms a linearly independent combination of the variables, which is stationary. The presence of cointegration suggests that there is a long-run stable relationship existing amongst these variables. If real deposit rates affect money, which in turn affects credit and hence investment, then the cointegration relationship is a conventional standard result. If there is a direct effect of money on the formation of physical capital, the presence of cointegration is a prerequisite for the complementarity hypothesis ${ }^{8}$.

\section{LONG-RUN AND DYNAMIC ERROR-CORRECTION MODEL}

\section{(a) Long-run model}

In panel estimations, the existence of unobservable determinants can be decomposed into a country-specific term and a common term for developing countries. The unobservable country-specific determinants can be taken into account in the estimation procedure, and models (3) and (4) respectively become:

$m / p_{i t}=\beta_{i, 0}+\beta_{1} y_{i, t}+\beta_{2} i / y_{i t}+\beta_{3}\left(d-\pi^{e}\right)_{i t}+\varepsilon_{i t}$

$i / y_{i t}=\alpha_{i, 0}+\alpha_{1}\left(d-\pi^{e}\right)_{i t}+\alpha_{2} d c_{i t}+\varepsilon_{i t}$

$\beta_{i, 0}$ and $\alpha_{i, 0}$ are a time-invariant individual country effect term and $\varepsilon_{i t}$ is an error term ${ }^{9}$. It is possible that country specific terms improved the estimates by absorbing country specific errors and reducing heteroskedasticity.

The cross-country regressions are subject to endogeneity problems. For example, the correlation between real deposit rates and money could arise from an endogenous 
determination of real rates, that is, real rates themselves may be influenced by innovations in the stochastic process governing the variable of money. Also, any omitted factors may increase both real rates and money simultaneously. In these circumstances there would exist a correlation between real deposit rates and the country-specific error terms in equation (5), which would bias the estimated coefficients. The endogeneity problem can be mitigated by applying instrument variable (IV) techniques. A good instrument would be a variable which is highly correlated with regressors, but not with the error terms. We use the lagged values of regressors and dependent variables in each equation. Besides, money is included as an instrument variable in the investment equation, and credit is in the money equation. This is not only due to the complementarity consideration, but also for the following reasons: Under disequilibrium financial conditions, where real deposit rates could be administered, being below equilibrium level, real credit supply is determined by real money demand and there is likely to be little direct feedback mechanism from investment demand to real credit. As there is limited supply (of savings), the volume of investment is determined solely by conditions of supply. In this respect, the use of money, as an instrument variable deals with any simultaneous equation bias in the investment estimate. However, where interest rate ceilings are relaxed or removed, a larger demand for investible funds will elicit an increase in quantity supplied through higher returns to savers. This consideration dictates the inclusion of credit as an instrument variable in the money equation.

By using IV techniques, we estimate the models in two ways: one is in a single equation framework, where money and investment are modelled separately, and the other is in a system of simultaneous equations, where both equations are simultaneously estimated. The estimates of the long-run models are shown in Table 1. An estimator that uses lags as instruments under the assumption of white noise errors would lose its consistency if, in fact, the errors were serially correlated ${ }^{10}$. It is, therefore, essential to satisfy oneself that this is not 
the case by reporting test statistics of the validity of the instrument variables. We present the first and second order residual serial correlation coefficients and the Sargan test of overidentifying restrictions together with the Breusch-Pagan-Godfray heteroskedasticity test. We also conducted the residual-based panel coingegration test of Pedroni (1999, 2004) and Kao (1999) for each single equation ${ }^{11}$. It is found that these residuals are $\mathrm{I}(0)$, and the evidence of stationarity seems to steer clear of 'spurious' regression.

\section{[Table 1 around here]}

The signs of all the coefficients agree with a priori expectations with a statistical significance, except for the real deposit rate in the system of money equation, which fails to reach the 5\% significance level. In general, the magnitude of the coefficients is larger in the single equation, as compared with that in the system equation. The investment model shows a remarkably similar size of coefficients between the system and single equations.

The positive relationship of the demand for money with the level of aggregate income accords with the transactions demand for money hypothesis. The sizes of the coefficient at 1.39 and 0.86 in the single and system equations respectively are quite plausible, being closer to those found in the empirical literature on the demand for money for developing economies $^{12}$. The positive impact of the investment income ratio on money supports the assumption of self-finance and indivisibility. Thus where self-finance is important, a rise in $i / y$ increases $m / p$. The estimated coefficient suggests that one percentage point increase in the investment ratio would increase the real money stock by about 0.16 to 0.19 percentage points. In the investment model, it is evident that the availability of credit raises the investment ratio, and the positive relationship with $d-\pi^{e}$ highlights the importance of high real rates of interest for capital accumulation. A crucial finding is the significant positive sign on $i / y$ in the money function and $d-\pi^{e}$ in the investment function, which provide robust empirical support for the complementarity hypothesis according to McKinnon's (1973) theory. 
Financial repression is deemed to be the holding of institutional interest rates, particularly of deposit rates of interest, below their market equilibrium levels. Our empirical evidence reveals that under disequilibrium interest rate conditions, higher deposit rates raise capital formation via the increase in real money balances, where money is defined broadly to include savings. The supply of credit is also dependent on the increased deposit rates, yet if there is a credit control prevalent ${ }^{13}$ and if we also consider such factors as external inflows and international trade in developing economies, there is a limitation in treating it as solely a direct consequence of the increased rates ${ }^{14}$. In this respect, the positive influence of deposit rates on investment is intuitive in terms of self-financed fixed capital, and proves to be a credible sign of the complementarity hypothesis.

\section{[Table 2 around here]}

For a comparative study, we present selected studies of the complementarity hypothesis in Table 2, where the estimates of level feedback are available in a similar model specification to that of this paper ${ }^{15}$. The income elasticity $(y)$ ranges from 0.45 to 1.17 in the literature and our estimates are quite comparable. The magnitude of the coefficient of investment ratio in our model is closer to that of Odhiambo (2005) for South Africa. As to real deposit rates, the existing literature tends to show either a very low magnitude of coefficients in both money and investment models, or even insignificant coefficients (see Khan and Hasan 1998 and Laumas 1990). This appears to indicate some difficulty in obtaining a well-determined estimate of $d-\pi^{e}$. In the $i / y$ model of this paper, the coefficients are 0.0054 to 0.0042 , which are similar to that found in Pentecost and Moore (2006).

\section{(b) Dynamic error correction model}

In order to ascertain the credibility of the long-run estimates, we investigate the dynamic behaviour of the demand for money and investment. Dynamic modelling in a system of 
equations is, however, not practically plausible with the small sample size in terms of time series relative to the number of explanatory variables: for example, a total of sixteen variables with one lag for each explanatory variable are to be simultaneously solved. Also note that, in general, there is not a sizeable difference in estimates between the system and single equations in Table 1 in the long-run model. Hence, we estimate the dynamic model in a single equation using the IV technique.

\section{[Table 3 around here]}

Tables 3 presents the dynamic, error correction model. The lagged error correction terms $\left(e_{t-1}\right)$, which are the residuals taken from the single equation of the long-run model, are specified along with the other explanatory variables by taking one lag for each. The respective error correction terms are found to be highly significant in each equation with the correct negative sign, indicating the appropriateness of the identified long-run relationships.

The explanatory variables are statistically and theoretically well-determined in the money equation: the level feedback from income, investment and real rates of interest is correctly signed. Similarly, in the dynamic investment model, the level feedback is statistically significant with a correct sign. The results overall seem to reinforce those of the long-run model.

\section{AUGMENTED INVESTMENT MODEL}

In the seminal work of McKinnon (1973), government fiscal action has little role in affecting directly aggregate capital accumulation, since public policy is limited to control of the real return on holding money (i.e. $d-\pi^{e}$ ). Further restrictions apply to the simplified assumptions about investment in small self-financing domestic enterprises. The models described are also derived from the assumptions for a closed economy, even though empirical material is usually drawn from small open economies ${ }^{16}$, where their rates of capital formation are 
unlikely to be determined solely by tiny self-financing units. Many developing countries are highly dependent on foreign trade and are open to corporate investment from abroad. Hence, a rise in investment may not be always due to a rise in the savings ratio when foreign trade or foreign capital flows are brought into the picture. McKinnon (1973) also fails to take account of the effect of financial development and the different income levels across countries, as these are treated as being constant. We relax these restrictions by augmenting the long-run investment models with several factors, which are likely to contribute to the share of financing in domestic capital formation.

Firstly, we consider financial development, which bring about financial innovation and eases some of the restrictions in the capital market, widening the scope for alternative investment opportunities, and removing barriers to entry for foreign banks. This is likely to impact on the transmission mechanism between deposit rates and investment. As a proxy variable, we explicitly include the development of the stock market and of broad money ${ }^{17}$. The latter may represent a deepening of the financial sector ${ }^{18}$. Secondly, the model is designed to reflect the different levels of income across developing countries. Depending on the level of institutional capability, on bureaucratic efficiency, on technological capability and on the quality of labour, deposit rates may affect investment differently. Assuming that these factors are, though in a crude manner, subsumed in the level of income, the estimation is conducted by taking dummy variables for two groups of low and upper-middle income countries to see if there is any difference in the linkage ${ }^{19}$.

Thirdly, external flows such as FDI (foreign direct investment) and ODA (official development assistance) are likely to affect capital formation independently of the level of real deposit rates. Foreign capital takes various forms. FDI implies long-term investment consisting of not only capital per se, but also management skill, know-how and technology, and FDI transmits technological diffusion from developed to developing countries, raising 
capital formation (Balasubramanyam et al. 1999 and Borensztein et al. 1998). Short-term foreign capital flows include portfolio investment and foreign bank lending. FDI is specified separately from short-term foreign loans, since the latter depend on the development of domestic financial markets, thus it is assumed to be captured through the variable of credit $^{20}$. ODA includes aid or concessional funds from such institutions as the IMF and the World Bank, and distinguishes itself from FDI, therefore ODA is shown as a separate entry in the model. Fourthly, we address the extent to which public spending is transmitted into capital and production. We condition investment decisions in the private sector by considering the improvement of infrastructure or the purchase of public capital ${ }^{21}$. Lastly, some attention is paid by the literature to foreign trade constraints on economic growth. Openness and trade policy are important for productivity spill-over and the cost of capital goods. More open economies have experienced faster productivity growth (Edwards 1998 and Diao et al. 2005), and developing countries can boost their productivity by importing a larger variety of intermediate products and capital equipment which embody foreign knowledge (Coe et al. 1997). A variable of foreign trade is added as a conditional instrument.

The augmented investment model is then given by:

$$
i / y=f\left(d-\pi^{e}, d c, v\right)
$$

where $v$ is the vector of additional explanatory variables: $f d_{i t}$ (financial development), $F D I_{i t}$, $O D A_{i t}, g_{i t}$ (government expenditure), trade ${ }_{i t}$ (foreign trade) and income dummy for low and upper-middle income groups. $f d$ and income dummy are specified as an interaction with real deposit rates. Financial development is the sum of the ratios of stock market capitalization, M2 and domestic credit to GDP. FDI, ODA, foreign trade, and government expenditure are all percentages of GDP. The country-income groups can be found in Appendix 2. The data are all retrieved from the World Development Indicator. The estimation is conducted using IV techniques with a country-specific dummy. 


\section{[Table 4 around here]}

Empirical results are reported in Table $4^{22}$. The coefficient of the interaction of deposit rates with financial development in Model 1 is negative. As the scope for obtaining funds from capital markets increases, reliance on self-finance may be curtailed. In Model 2 and 3, the interaction between the real deposit rate and the upper-middle income group is shown to be negative, whereas that for the low-income countries is positive. This implies that as the status of a developing country moves from the low to the middle income group, there is less self-financed investment. These results are not surprising and explain why some empirical literature rejects the hypothesis. For example, Fry (1978) finds that money is not the only financial repository of domestic saving for the seven Asian semi-industrial LDCs. This is because these countries have achieved stages of financial development well beyond the phase in which the complementarity assumptions predominate ${ }^{23}$. In the empirical work for 25 Asian and Latin American LDCs, Gupta (1984) did not find strong support for the complemetarity hypothesis. It is noted that some of the major Latin American countries in Gupta's study are classified as being in the upper-middle income bracket.

The impact of FDI and ODA in Model 4 also accords with a priori expectations, indicating that, as the external flows increase the amount of investment is raised, being independent of the complementarity hypothesis ${ }^{24}$. Note that the effect of ODA on capital formation is weak, as the size of the coefficient is much smaller than that of FDI, and also in Model 5 and 6, the coefficient is not significant at the 5\% level. Generally, in order for ODA to affect output greatly, countries need to be equipped with reasonably well-developed institutions and legal systems. Moreover, aid could be often misallocated into financing consumption expenditure by the government or reserve accumulation (in particular when exchange rates are fixed), rather than increasing productive capital formation. These factors 
may, in part, explain the weak effect of ODA. Public finance (Model 5) and trade openness (Model 6) have a positive and significant impact.

The robust finding is that $d-\pi^{e}$ is statistically significant, even when the investment model is conditioned. It is, however, worth noting that there is a sharp decline in the magnitude of the coefficient, when such factors as external flows, trade and public finance are specified in the model as compared with that in Table 1. In this respect, although the real rate of return on money matters in the creation of investment opportunities due to selffinanced capital formation, the complementarity hypothesis may be of limited practical value. Meanwhile, the robustness of the size of the coefficient of the credit can be observed, which remains mostly closer to the coefficient of 0.0018 in Table 1.

\section{CONCLUSION}

This paper has extensively tested McKinnon's complementarity hypothesis for 107 developing countries using panel cointegration and IV econometric techniques. The results show that the real rates of interest have a positive effect on money and investment, hence McKinnon's emphasis on the importance of financial conditions in the development process is justified. Our results substantiate the earlier findings for individual countries for selffinanced capital formation. However, at the same time, we find that the effect weakens when the investment model is augmented with conditional variables. Also, complemetarity is not supported in the middle-income group of countries, nor when a country reaches a certain stage of financial market development. In this respect, one may have to look much farther down the development ladder, well below the middle-income level of developing economies, to the world's least developed countries in order to recognise the complementarity theory. The evidence appears to highlight the strength of the credit link along with the role of financial intermediation ${ }^{25}$. Under the disequilibrium interest rate system, which characterises 
most developing countries, a decline in the real deposit rate of interest reduces real money demand, which affects real credit supply, and this, in turn, squeezes new fixed investment. In either self-financed or bank-loan financed capital formation, the real rate of return on money greatly matters in raising the formation of capital, thereby increasing the rate of economic growth. Policy makers for developing economies should continue to ensure a policy aimed at changing negative real interest rates to positive levels, or improve positive rates in order to secure greater levels of investment.

\section{APPENDIX 1}

\section{7 developing countries (out of total 149) used for the empirical analysis}

Low-income economies (39)

Bangladesh

Benin

Burkina Faso

Burundi

Cambodia

Central African Republic

Chad

Côte d'Ivoire

Ethiopia

Gambia, The

Ghana

Guinea-Bissau

Haiti
India

Kenya

Kyrgyz Republic

Lao PDR

Madagascar

Malawi

Mali

Mauritania

Mozambique

Myanmar

Niger

Nigeria

Pakistan
Papua New Guinea

Rwanda

Senegal

Sierra Leone

Solomon Islands

Sudan

Tanzania

Togo

Uganda

Vietnam

Yemen, Rep.

Zambia

Zimbabwe

\section{Lower-middle-income economies (38)}

$\begin{array}{lll}\text { Albania } & \text { Ecuador } & \text { Morocco } \\ \text { Algeria } & \text { Egypt, Arab Rep. } & \text { Nicaragua } \\ \text { Armenia } & \text { El Salvador } & \text { Paraguay } \\ \text { Azerbaijan } & \text { Fiji } & \text { Peru } \\ \text { Belarus } & \text { Georgia } & \text { Philippines } \\ \text { Bhutan } & \text { Guatemala } & \text { Sri Lanka } \\ \text { Bolivia } & \text { Guyana } & \text { Swaziland } \\ \text { Cameroon } & \text { Honduras } & \text { Syrian Arab Republic } \\ \text { Cape Verde } & \text { Indonesia } & \text { Thailand } \\ \text { China } & \text { Jordan } & \text { Tunisia } \\ \text { Colombia } & \text { Lesotho } & \text { Ukraine } \\ \text { Congo, Rep. } & \text { Macedonia, FYR } & \text { Vanuatu } \\ \text { Dominican Republic } & \text { Moldova } & \end{array}$


Upper-middle-income economies (30)

$\begin{array}{lll}\text { Argentina } & \text { Grenada } & \text { Russian Federation } \\ \text { Belize } & \text { Hungary } & \text { Serbia } \\ \text { Botswana } & \text { Latvia } & \text { Seychelles } \\ \text { Brazil } & \text { Libya } & \text { Slovak Republic } \\ \text { Bulgaria } & \text { Lithuania } & \text { South Africa } \\ \text { Chile } & \text { Malaysia } & \text { St. Kitts and Nevis } \\ \text { Costa Rica } & \text { Mauritius } & \text { St. Vincent and the } \\ & & \text { Grenadines } \\ \text { Croatia } & \text { Mexico } & \text { Turkey } \\ \text { Dominica } & \text { Panama } & \text { Uruguay } \\ \text { Gabon } & \text { Poland } & \text { Venezuela, RB }\end{array}$

Economies are divided according to 2006 GNI per capita,. Low income countries ( $\$ 905$ or less) 39 out of 53,

Lower-middle income countries (\$906-\$3,595) 38 out of 55 countries and upper-middle income countries (\$3,596 -\$11,115) 30 out of 41 countries (World Development Indicator).

\section{APPENDIX 2}

\section{Descriptive statistics}

\begin{tabular}{llrrrr}
\hline & $m / p$ & \multicolumn{1}{l}{$i / y$} & \multicolumn{1}{c}{$d c$} & \multicolumn{1}{c}{$y$} & \multicolumn{1}{c}{$d-\pi^{e}$} \\
\hline Mean & 20.755 & -1.593 & 30.454 & 24.853 & -3.140 \\
Median & 21.312 & -1.585 & 21.877 & 25.575 & 0.547 \\
Maximum & 29.688 & -0.193 & 234.180 & 35.154 & 231.427 \\
Minimum & 14.145 & -4.337 & -72.994 & 0.595 & -298.95 \\
Std. Dev. & 3.497 & 0.476 & 30.261 & 4.667 & 22.858 \\
\hline
\end{tabular}
a. Sample period 1970-2006 with 107 countries.
b. Observations 2050 .
c. $\quad d-\pi^{e}$ : The values above and below $300 \%$ are removed. 


\section{REFERENCES}

Balasubramanyam, V.N., Salisu, M \& Sapsford D. (1999). Foreign Direct Investment as an Engine of Growth. Journal of International Trade and Economic Development, 8, 2740.

Blomstrom, M., Lipsey, R. \& Zejan, M. (1996). Is fixed investment the key to economic growth? Quarterly Journal of Economics, 111(2), 269-276.

Borenszstein, E. J. G \& Lee, J.W. (1998). How Does Foreign Direct Investment affect Economic Growth? Journal of International Economics, 45, 115-35.

Bosworth, B.P. \& Collins, S.M. (1999). Capital flows to developing economies: implications for saving and investment. Brookings Papers on Economic Activity, 1, 143-180.

Chatterjee, S. \& Turnovsky, S.J. (2007) Foreign aid and economic growth: The role of flexible labor supply. Journal of Development Economics, 84, 507-533.

Coe D., Helpman, E \& Hoffmeister, A. (1997). North-South R \& D spillovers. Economic Journal, 107, 134-149.

De Melo, J. \& Tybout, J. (1986). The Effects of Financial Liberalisation on Savings and Investment in Uruguay. Economic Development and Cultural Change, 34 (April): 561587.

Diao X., Rattsø J. \& Stokke, H.E. (2005). International spillovers, productivity growth and openness in Thailand: an intertemporal general equilibrium analysis. Journal of Development Economics, 76, 429-450.

Dickey, D.A., Jansen, D.W. \& Thornton, D.L. (1994). A primer on cointegration with an application to money and income. In Rao, B.B. (Ed.), Cointegration for the Applied Economist, St. Martin's Press, Inc.

Edwards, S. (1988). Financial Deregulation and Segmented Capital Markets: The Case of Korea. World Development, 16 (1):185-194. 
Edwards, S. (1998). Openness, productivity and growth: what do we really know? Economic Journal, 108, 383-398.

Fisher, R. A. (1932). Statistical Methods for Research Workers (4th ed.). Edinburgh: Oliver \& Boyd.

Fry, M.J. (1978), Money and capital or financial deepening in economic development. Journal of Money, Credit and Banking, 10 (November), 464-475.

Fry, M.J. (1980). Saving, investment, growth and the cost of financial repression. World Development, 8, 317-327.

Gupta, K.L. (1984). Finance and economic growth in developing countries. London: Croom Helm Ltd.

Harris, J.W. (1979). An Empirical Note on the Investment Content of Real Output and the Demand for Money in the Developing Economy. Malayan Economic Review, 24, 49-59. Harris, R. (1995). Using Cointegration Analysis in Econometric Modelling. Hemel Hempstead, UK: Prentice Hall.

Im, K.S., Pesaran, M.H. \& Shin, Y. (2003). Testing for unit roots in heterogeneous panels. Journal of Econometrics, 115(1.2) 53-74.

Kao, C. (1999). Spurious regression and residual-based tests for cointegration in panel data. Journal of Econometrics, 90, 1-44.

Khan, A. (1988). Financial repression, financial development and the structure of savings in Pakistan. Pakistan Development Review, 27(Winder), 701-711.

Khan, A.H. \& Hasan, L. (1998). Financial Liberalisation, Savings and Economic Development in Pakistan. Economic Development and Cultural Change, 46 (April), 581-597.

Laumas, P.S. (1990). Monetisation, Financial Liberalisation and Economic Development. Economic Development and Cultural Change, 38 (January), 377-390. 
Levin, A., Lin, C.F. \& Chu, C.S. (2002). Unit root tests in panel data: Asymptotic and finitesample properties. Journal of Econometrics, 108(1), 1-24.

Leff, N.H. \& Sata, K. (1980). Macroeconomic adjustment in developing countries: instability, short-run growth and external dependency. Review of Economics and Statistics, 62(2) May, 170-179.

MacKinnon, J.C., Huag, A.A. \& Michelis, L. (1999). Numerical distribution functions of likelihood ratio tests for cointegration. Journal of Applied Econometrics, 14, 563-577.

Maddala, G.S. \& Wu, S. (1999). A comparative study of unit root tests with panel data and a new simple test. Oxford Bulletin of Economics and Statistics, 61, 631-652.

Mallick, S. \& Moore, T. (2008) Foreign Capital in a Growth Model. Review of Development Economics, 12(1), 143-159.

McKinnon, R.I. (1973). Money and Capital in Economic Development. Washington DC: The Brookings Institution.

Moore, T., Green, C.J. \& Murinde, V. (2005) Portfolio Behaviour in a Flow of Funds Model for the Household in India. Journal of Development Studies, 41(4 April), 675-702.

Morriset, J. (1993). Does financial liberalisation really improve private investment in developing countries? Journal of Development Economics, 40 (1), 133-150.

Odhiambo, N.M. (2005). Money and capital investment in South Africa: A dynamic specification model. Journal of Economics and business, 57, 247-258.

Pedroni, P. (1999). Critical values for cointegration tests in heterogenous panels with multiple regressors. Oxford Bulletin of Economics and Statistics, 61, 653-670.

Pedroni, P. (2004). Panel cointegration; Asymptotic and finite sample properties of pooled time series tests with an application to the PPP hypothesis. Econometric Theory, 20, $597-625$.

Pentecost, E.J. \& Moore, T. (2006). Financial liberalisation in India and a new test of 
McKinnon's complementarity hypothesis. Economic Development and Cultural Change, 54(2), 487-502.

Pentecost, J.E. \& Ramlogan, C. D (2000). The savings ratio and financial repression in Trinidad and Tobago. International Economic Journal, 14(2), 67-84

Shaw, E.S. (1973). Financial deepening in economic development. New York: Oxford University Press.

Thornton, J. (1990). The Demand for Money in India: A Test of McKinnon's Complementarity Hypothesis. Savings and Development, 14, 153-157.

Thornton, J. \& Poudyal, S.R. (1990). Money and capital in economic development: A test of the McKinnon hypothesis for Nepal. Journal of Money, Credit and Banking, 22 (August), 395-399. 
Table 1 Long-run IV model: Single and system equations

\begin{tabular}{|c|c|c|c|c|c|c|c|c|c|}
\hline Dependent var. & Single & & System & & Dependent Var. & Single & & System & \\
\hline$m / p$ & Coef & s.e. & Coef & s.e. & $i / y$ & Coef & s.e. & Coef & s.e. \\
\hline Constant & $-14.40904 * * *$ & 0.70002 & $-1.15561 * * *$ & 0.28134 & Constant & $-1.62199 * * *$ & 0.01730 & $-1.59951 * * *$ & 0.01426 \\
\hline$y$ & $1.39099 * * *$ & 0.02691 & $0.86769 * * *$ & 0.01056 & $d-\pi^{e}$ & $0.00542 * * *$ & 0.00071 & $0.00425^{* * *}$ & 0.00122 \\
\hline$i / y$ & $0.16255^{* * *}$ & 0.02950 & $0.19578 * *$ & 0.08479 & $d c$ & $0.00189 * * *$ & 0.00046 & $0.00172 * * *$ & 0.00030 \\
\hline$d-\pi^{e}$ & $0.00077 * *$ & 0.00036 & 0.00027 & 0.00060 & & & & & \\
\hline$R^{2}$ & 0.990 & & 0.727 & & & 0.608 & & 0.522 & \\
\hline Breusch-God (order=1) & 1.3339 & & $4.5767 \dagger$ & & & 1.9018 & & 2.0568 & \\
\hline Breusch-God. (order=2) & 1.2503 & & 5.1161 & & & 1.2513 & & 1.2082 & \\
\hline Breusch-Pagan & 1.7825 & & 1.9247 & & & 2.3814 & & 4.1219 & \\
\hline Sargan & 1.0680 & & 1.8904 & & & 5.4983 & & 1.5579 & \\
\hline
\end{tabular}

a. In the system of question, $m / p$ and $i / y$ models are simultaneously estimated by the maximum likelihood estimation.

b. $* * *, * *$ and $*$ Significant at the $1 \%, 5 \%$ and $10 \%$ level.

c. IV (instrument variables) in $t-1: m / p, y, i / y, d-\pi^{e}$ and $d c$ for $m$ equation and $m / p, d c, i / y$ and $d-\pi^{e}$ for $i / y$ equation.

d. $\quad \chi^{2}$ tests for Breusch-Godfrey serial correlation (AR), Breusch-Pagan-Godfrey hetroskedasticity, and Sargan over-identification. $\dagger$ indicate significant at the $5 \%$ level. 
Table 2 Selected studies of the complementary demand for money in developing economies

\begin{tabular}{|c|c|c|c|c|c|c|c|}
\hline & Countries & $\begin{array}{c}\text { Period } \\
\text { (annual data) }\end{array}$ & Model & $y$ & $d-\pi^{e}$ & $i / y$ & Estimation Methodology \\
\hline Table 1 & $\begin{array}{l}\text { 108 LDCs } \\
\text { Panel data }\end{array}$ & $1970-2006$ & $\mathrm{~m} / \mathrm{p}$ & 1.39099 & 0.00077 & 0.1625 & Single IV \\
\hline “ & & & $m / p$ & 0.86769 & $0.00027 \S$ & 0.1957 & System IV \\
\hline “ & & & $i / y$ & & 0.00542 & & Single IV \\
\hline “" & & & $i / y$ & & 0.00425 & & System IV \\
\hline $\begin{array}{l}\text { Pentecost and } \\
\text { Moore (2006) }\end{array}$ & India & 1951-1999 & $m / p$ & 0.448 & 0.057 & 0.683 & System, Cointegration found \\
\hline “ & & & $i / y$ & & 0.004 & & System, Cointegration found \\
\hline $\begin{array}{l}\text { Odhiambo } \\
\text { (2005) }\end{array}$ & South Africa & & $m / p$ & 0.45484 & 0.0106 & $0.19891 *$ & OLS, Dynamic level feedback \\
\hline $\begin{array}{l}\text { Khan and } \\
\text { Hasan (1998) }\end{array}$ & Pakistan & $\begin{array}{l}1959 / 60- \\
1994 / 95\end{array}$ & $m / p$ & 1.02 & $0.0015 \S$ & $1.97 *$ & OLS, Cointegration found \\
\hline “ & & & $\begin{array}{l}m / p \\
i / p\end{array}$ & 1.07 & $\begin{array}{l}0.003 \S \\
0.0005 \S\end{array}$ & 1.39 & $\begin{array}{l}\text { OLS, Cointegration found } \\
\text { OLS, Cointegration found }\end{array}$ \\
\hline $\begin{array}{l}\text { Laumas } \\
(1990) \\
\text { ، }\end{array}$ & India & $\begin{array}{l}1954 / 55- \\
19971 / 72\end{array}$ & $\begin{array}{l}m / p \\
i / y\end{array}$ & 0.143 & $\begin{array}{l}0.09 \S \\
0.014\end{array}$ & $72.343 \S$ & $\begin{array}{l}\text { System IV } \\
\text { Time deposit instead of money } \\
\text { System IV }\end{array}$ \\
\hline $\begin{array}{l}\text { Thornton and } \\
\text { Poudyal } \\
\text { (1990) }\end{array}$ & Nepal & $\begin{array}{l}1974 / 75- \\
1986 / 87\end{array}$ & $m / p$ & 1.1734 & -0.0137 & $0.0708 *$ & Single IV \\
\hline $\begin{array}{l}\text { Thornton } \\
\text { (1990) }\end{array}$ & India & 1964-1984 & $m / p$ & 0.9235 & -0.0039 & $1.0642 *$ & Single IV \\
\hline
\end{tabular}

a. IV: Instrumental variables.

b. * Domestic saving $\left(s_{d /} y\right)$ specified instead of investment.

c. $\S$ Insignificant at the $5 \%$ level. 
Table 3 Error correction dynamic model: IV model

\begin{tabular}{|c|c|c|c|c|c|}
\hline $\begin{array}{c}\text { Dependent var.: } \\
\Delta(m / p)\end{array}$ & coef & s.e. & $\begin{array}{c}\text { Dependent var.: } \\
\Delta(i / y)\end{array}$ & Coef. & s.e. \\
\hline Constant & $0.03286^{* * *}$ & 0.00477 & Constant & -0.00729 & 0.00755 \\
\hline$e_{t-1}$ & $-0.13385^{* * *}$ & 0.01034 & $e_{t-1}$ & $-0.29008 * * *$ & 0.04187 \\
\hline$\Delta(m / p)_{t-1}$ & $-0.04818 * *$ & 0.02389 & $\Delta(i / y)_{t-1}$ & $0.11346^{* * * *}$ & 0.04313 \\
\hline$\Delta y$ & $0.52418 * * *$ & 0.07317 & $\Delta\left(d-\pi^{e}\right)$ & $0.00325 * *$ & 0.00164 \\
\hline$\Delta y_{t-1}$ & $0.16080 * *$ & 0.07353 & $\Delta\left(d-\pi^{e}\right)_{t-1}$ & -0.00008 & 0.00039 \\
\hline$\Delta i / y$ & $0.09109 * * *$ & 0.02070 & $\Delta d c$ & $0.02526 * * *$ & 0.00558 \\
\hline$\Delta i / y_{t-1}$ & -0.00353 & 0.02019 & $\Delta d c_{t-1}$ & $-0.00834 *$ & 0.00454 \\
\hline$\Delta\left(d-\pi^{e}\right)$ & $0.00140 * * *$ & 0.00018 & & & \\
\hline$\Delta\left(d-\pi^{e}\right)_{t-1}$ & $0.00098 * * *$ & 0.00016 & & & \\
\hline$R^{2}$ & 0.336 & & & 0.305 & \\
\hline $\begin{array}{l}\text { Breusch-God. } \\
\text { (order=1) }\end{array}$ & 3.8168 & & & 1.1350 & \\
\hline $\begin{array}{l}\text { Breusch-God. } \\
\text { (order=2) }\end{array}$ & 4.7459 & & & 3.2429 & \\
\hline Breusch-Pagan & 6.0494 & & & 1.2313 & \\
\hline Sargan & 7.1428 & & & 4.9235 & \\
\hline
\end{tabular}

a. $* * *, * *$ and $*$ Significant at the $1 \%, 5 \%$ and $10 \%$ level.

b. IV (instrument variables) in $t$-3and $t$-4 in levels: $m / p, y, i / y d-\pi^{e}$ and $d c$ in $\Delta(m / p)$ equation and $m / p, d c, i / y$ and $d-\pi^{e}$ in $\Delta(i / y)$ equation.

c. $\chi^{2}$ tests for Breusch-Godfrey serial correlation, Breusch-Pagan-Godfrey hetroskedasticity, and Sargan overidentification (none is significant at the $5 \%$ level). 
Table 6 IV estimates of the augmented investment model: dependent variable $i / y$

\begin{tabular}{lllllll}
\hline & Model 1 & s.e. & Model 2 & s.e. & Model 3 & s.e. \\
\hline Constant & $-1.61622^{* * *}$ & 0.01872 & $-1.62912^{* * *}$ & 0.01647 & $-1.58332 * * *$ & 0.02083 \\
$d-\pi^{e}$ & $0.01113^{* * *}$ & 0.00344 & $0.00090^{* * *}$ & 0.00047 & $0.00943^{* * * *}$ & 0.00201 \\
$d c$ & $0.00220^{* * *}$ & 0.00047 & $0.00194 * * *$ & 0.00044 & $0.00126^{* * *}$ & 0.00047 \\
$d-\pi^{e} * f d$ & $-0.00023^{* * *}$ & 0.00008 & & & & \\
$d-\pi^{e} *$ low & & & $0.00245^{* * *}$ & 0.00074 & & \\
$d-\pi^{e} *$ middle & & & & & $-0.02463^{* * *}$ & 0.00985 \\
$R^{2}$ & & & 0.643 & & 0.491 & \\
$\begin{array}{l}\text { Breusch-God. } \\
\text { (order=1) }\end{array}$ & $4.6410 \dagger$ & & 1.0751 & & 2.0374 & \\
$\begin{array}{l}\text { Breusch-God. } \\
\text { (order=2) }\end{array}$ & 4.3062 & & 1.0097 & & 1.9463 & \\
$\begin{array}{l}\text { Breusch-Pagan } \\
\text { Sargan }\end{array}$ & 4.7350 & & 1.1776 & & 6.8591 & \\
\hline
\end{tabular}

\begin{tabular}{|c|c|c|c|c|c|c|}
\hline & Model 4 & s.e. & Model 5 & s.e. & Model 6 & s.e. \\
\hline Constant & $-1.67206^{* * * *}$ & 0.02021 & $-1.76481 * * *$ & 0.03752 & $-1.96708^{* * *}$ & 0.04643 \\
\hline$d-\pi^{e}$ & $0.00203 * * *$ & 0.00060 & $0.00179 * * *$ & 0.00060 & $0.00192 * * *$ & 0.00060 \\
\hline$d c$ & $0.00184 * * *$ & 0.00044 & $0.00174 * * *$ & 0.00045 & 0.00029 & 0.00044 \\
\hline FDI & $1.19250 * * *$ & 0.21905 & $1.24639 * * *$ & 0.21986 & $1.08370^{* * *}$ & 0.20691 \\
\hline$O D A$ & $0.35494 * *$ & 0.16534 & $0.29919 *$ & 0.16633 & 0.26230 & 0.16835 \\
\hline$g$ & & & $0.00707^{* * *}$ & 0.00239 & $0.00797 * * *$ & 0.00244 \\
\hline Trade & & & & & $0.00300^{* * *}$ & 0.00039 \\
\hline$R^{2}$ & 0.663 & & 0.666 & & 0.673 & \\
\hline $\begin{array}{l}\text { Breusch-God. } \\
\text { (order=1) }\end{array}$ & $4.9517 \dagger$ & & $4.941546 \dagger$ & & $4.932963 \dagger$ & \\
\hline Breusch-God. & 4.6512 & & 4.636248 & & 4.638195 & \\
\hline & 4.2584 & & 5.16021 & & 6.091411 & \\
\hline $\begin{array}{l}\text { Breusch-Pagan } \\
\text { Sargan }\end{array}$ & 4.7923 & & 4.7628 & & 4.5233 & \\
\hline
\end{tabular}

a. $* * *, * *$ and $*$ Significant at the $1 \%, 5 \%$ and $10 \%$ level.

b. IV (instrument variables) in $t-1: m / p, i / y$ and all regressors in each model.

c. $\chi^{2}$ tests for Breusch-Godfrey serial correlation, Breusch-Pagan-Godfrey hetroskedasticity, and Sargan overidentification. $\dagger$ indicate significant at the $5 \%$ level. 


\section{ENDNOTES}

${ }^{1}$ Shaw (1973) argues that complementarity has no place here because investors are not constrained to selffinance. Shaw took the debt-intermediation view by specifying a vector of real opportunity costs (real yields on all types of wealth) of holding money in equation (1).

${ }^{2}$ McKinnon (1973) suggested using the average return on capital among firms. However, it is not possible to compute such a unique rate of return, even for a single country (Laumas 1990).

3 We removed the observations of real deposit rates, which exceeded $300 \%$ in absolute values. The choice of $300 \%$ is based on statistical performance. This has improved the numerical value of the coefficient of the real deposit rate, whilst the overall results remain to be similar to those with such extreme values.

${ }^{4}$ Gross fixed capital formation includes plant, machinery, office, equipment purchases, private residential dwellings, commercial and industrial buildings and also the construction of roads, railways, schools and hospitals. There is no data available exclusively for private investment for many of these developing countries. However, there exists disaggregated data for private and government consumption expenditures, respectively. Hence, we derive the private sector investment by taking the ratio of private sector consumption expenditure to total consumption expenditure (private and government sectors), as a weight on the gross fixed capital formation. Although, the use of the weight may not accurately reflect the level of private investment, it may, broadly, exclude the governments' element of capital formation.

${ }^{5}$ In the preliminary estimation, we specified inflation expectations by taking the moving average type of autoregressive expectation. Also, some exercises, by taking a weight of the present and past inflation, were conducted. However, these attempts were not quite successful, having poorly determined coefficients. We stay with the naïve expectation.

${ }^{6}$ In order to save space, the test results are not presented here, but available from the author upon request.

${ }^{7}$ Dickey et al. (1994) argue that cointegration vectors may represent constraints on the movement of the variables in the system in the long-run, and consequently, the more cointegrating vectors there are, the more stable the system is.

${ }^{8}$ Some empirical literature finds cointegration (see Table 2 in this paper) and claims it as compelling evidence of the complementarity hypothesis. This overrates the findings.

${ }^{9}$ The period effects are found to be insignificant by the likelihood ratio test, therefore we do not specify the period dummy. It is possible that the regressors may capture some of the shifts in the economy over the sample 
period. In the next section, when the model is augmented, such period effects are more likely to be subsumed in the controlled variables, hence we do not give it much weight.

${ }^{10}$ Note also that the use of lagged variables as instruments is said to be a weak procedure. I thank one of the referees of this journal for pointing this out.

${ }^{11}$ Pedroni (1999 and 2004) proposes to allow for heterogeneous intercepts and trend coefficients across crosssections. The Kao's (1999) test specifies the cross-section specific intercepts and homogeneous coefficients across cross-sections, and sets all of the trend coefficients to zero. The results are available from the author upon request.

${ }^{12}$ See the selected studies in Table 11 in Moore et al. (2005) for the income elasticities of the demand for money for developing economies.

${ }^{13}$ The monetary authorities may generate new credit independently of domestic saving often in response to government policy.

${ }^{14}$ The supply of real credit is also determined by the balance of payments situation (Leff and Sato 1980).

${ }^{15}$ One of the earliest empirical works is in Fry (1978), who rejected the complementarity hypothesis for seven less-developed countries in Asia in a pooled regression. Since Fry's model specification and estimation techniques are different from those used in this paper, they are not listed in Table 2.

${ }^{16}$ Much of the empirical literature is based on closed economies. For exceptions, see Pentecost and Ramlogan (2000), who used two alternative measures of exchange rate misalignment in investigating the financial repression hypothesis for Trinidad and Tobago.

${ }^{17}$ The variable of credit is combined with these variables, so that they capture the financial development in a wider range.

${ }^{18}$ One may prefer to hold monetary assets only when it is felt convenient to keep ones' wealth in monetary instruments with an underlying nature of liquidity, risk, return and efficiency in payment. Such types of instruments are offered by a better-developed financial sector.

${ }^{19}$ In the preliminary results, the group of lower-middle income countries performs poorly, hence we concentrate on low and upper-middle income groups.

${ }^{20}$ See, for example, Bosworth and Collins (1999) for justification.

${ }^{21}$ For example, Chatterjee and Turnovsky (2007) argue that the effectiveness of foreign capital on investment depends on the condition of public finances. 
${ }^{22}$ The models, in general, tend to suffer a first-order serial correlation at the 5\% level, but not at the $1 \%$ level. The second-order serial correlation is not rejected at the $5 \%$ level in all cases.

${ }^{23}$ In Fry's (1978) study, three out of the seven countries are not even categorised as developing countries now.

${ }^{24}$ Empirically, the impact of FDI on economic growth has remained controversial. Our results are in line with those of Blomstrom et al. (1996), Balasubramanyan et al. (1999) and Borensztein et al. (1998), who observe a positive impact.

${ }^{25}$ Indeed, McKinnon (1973) argued for the desirability of increasing the flow of credit through financial intermediaries in order to raise the level of capital formation. 